\title{
Implementasi Metode AHP dan Promethee Untuk Pemilihan Supplier
}

\author{
Ahmad Abdul Chamid $^{\mathrm{a}^{*}}$, Bayu Surarso ${ }^{\mathrm{b}}$, Farikhin $^{\mathrm{b}}$ \\ ${ }^{a}$ Fakultas Teknik, Universitas Muria Kudus \\ ${ }^{\mathrm{b}}$ Jurusan Matematika, Fakultas Sains dan Matematika, Universitas Diponegoro
}

Naskah Diterima : 13 Mei 2015; Diterima Publikasi : 13 Juli 2015

\begin{abstract}
Selection of suppliers is one of the most important things to meet the needs of the company consistently and at an acceptable cost, decision support system used to select suppliers by identifying suppliers with the highest potential. The object of this study is the drug suppliers. In this study we use four criterias to select suppliers of drugs: drug completeness, price, time delivery, payment or loan term. AHP method is used to calculate the weight of each criterion based on the pharmacist assessment. The weight criterias of the AHP process result is used for the calculation of the alternatives rank. PROMETHEE method used to alternatives calculation analysis that produce alternatives rankings.
\end{abstract}

Keywords: Supplier; Decision Support Systems; AHP; PROMETHEE

\begin{abstract}
Abstrak
Pemilihan pemasok merupakan salah satu hal terpenting untuk memenuhi kebutuhan perusahaan secara konsisten dan tanpa biaya yang mahal, untuk memilih pemasok digunakan sistem pendukung keputusan dengan cara mengidentifikasi pemasok dengan potensi tertinggi. Objek penelitian ini yakni pemasok obat. Dalam penelitian ini digunakan empat kriteria untuk memilih pemasok obat yakni: kelengkapan obat, harga, waktu pengiriman, pembayaran atau jangka kredit. Metode AHP digunakan untuk menghitung bobot setiap kriteria berdasarkan penilaian dari para apoteker. Bobot kriteria dari hasil AHP digunakan untuk perhitungan peringkat alternatif. Metode PROMETHEE digunakan untuk analisis perhitungan alternatif sehingga menghasilkan rangking alternatif.
\end{abstract}

Kata Kunci: Supplier; Sistem Pendukung Keputusan; AHP; PROMETHEE

\section{Pendahuluan}

Pemilihan pemasok merupakan salah satu yang paling penting dalam pengambilan keputusan termasuk kedua faktor kualitatif dan kuantitatif untuk mengidentifikasi pemasok dengan potensi tertinggi untuk memenuhi kebutuhan perusahaan secara konsisten dan tanpa biaya yang mahal (Safari et al., 2012). Untuk memilih pemasok yang dapat dikatakan layak dan sesuai dengan kriteria perusahaan, tentunya dibutuhkan sistem pendukung keputusan. Sistem pendukung keputusan merupakan sistem yang digunakan untuk membantu dalam penyelesaian masalah dan dukungan keputusan.

Multi criteria decision making (MCDM) mampu mengevaluasi sebuah website perhotelan. Kombinasi metode AHP dengan PROMETHEE digunakan untuk evaluasi kualitas website perhotelan. AHP memberikan pendekatan analitik untuk menimbang kriteria. Evaluasi alternatif sesuai dengan kriteria yang ditimbang disediakan melalui PROMETHEE yang memungkinkan pengambil keputusan untuk mendapatkan peringkat parsial dan lengkap (Akincilar dan Dagdeviren, 2014). Metode PROMETHEE dengan Entropy digunakan untuk seleksi pemasok. Entropy digunakan untuk menghitung bobot dari setiap kriteria. Setelah itu PROMETHEE digunakan untuk menentukan peringkat alternatif (Safari et al., 2012).

Pada berbagai metode MCDM, metode outranking memiliki perkembangan pesat karena fleksibilitas mereka hingga situasi keputusan yang nyata. Metode PROMETHEE adalah yang paling dikenal dan banyak digunakan metode outranking untuk sepasang perbandingan bijaksana alternatif disetiap kriteria terpisah (Vinodh dan Girubha, 2012).

Metode PROMETHEE merupakan salah satu metode multi criteria decision making (MCDM) yang menggunakan metodologi outranking untuk peringkat alternatif (Yu et al., 2013). PROMETHEE memerlukan dua masukan selain nilai evaluasi

*) Penulis korespondensi: chamidgeovani@gmail.com 
alternatif dalam hal masing-masing kriteria, yaitu: bobot kriteria, jenis fungsi masing-masing kriteria dipertimbangkan dalam masalah pengambilan keputusan (Akincilar dan Dagdeviren, 2014). Metode PROMETHEE digunakan untuk menentukan peringkat akhir, bersama dengan perubahan bobot untuk analisis sensitivitas (Wang dan Yang, 2006). Metode PROMETHEE merupakan kelas baru metode outranking dalam analisis multikriteria. Fitur utama mereka adalah kesederhanaan, kejelasan dan stabilitas (Brans et al., 1986).

Metode PROMETHEE telah digunakan untuk menyelesaikan masalah bagi pengambilan keputusan dalam perdagangan saham, pemilihan saham yang tepat pada waktu yang tepat, mengembangkan model pengambilan keputusan untuk memilih saham unggulan di bursa dan model disediakan untuk struktur masalah ini. Model yang diusulkan disusun sekitar dua pilar: evaluasi industri dan evaluasi perusahaan. Dengan menerapkan metode PROMETHEE untuk analisis sensitivitas dari hasil, juga dapat membantu investor meningkatkan struktur evaluasi industri dan evaluasi perusahaan (Albadvi et al., 2007).

Metode PROMETHEE pernah digunakan untuk evaluasi empat pemasok outsourcing yang potensial, menggunakan tujuh kriteria dan empat pengambil keputusan. Hasil rangking memberikan referensi yang membantu para pengambil keputusan yang ingin meningkatkan efisiensi proses keputusan pada sistem informasi outsourcing (Ying-Hsiu et al., 2011 dalam Yu dan MA, 2013).

Metode AHP dan PROMETHEE pernah digunakan untuk pemilihan pemasok sayuran di supermarket. Penilaian terhadap kuesioner matriks perbandingan berpasangan dilakukan oleh lima orang yaitu 2 orang dari bagian penerimaan, dua orang dari bagian pembelian dan manajer, penentuan bobot kriteria menggunakan metode AHP. Untuk memilih pemasok sayuran menggunakan sepuluh kriteria, ada 3 dari 10 kriteria yang tidak dapat digunakan pada perhitungan PROMETHEE, karena tidak memberikan perbedaan nilai yang signifikan di antara para pemasok yang akan dinilai. Untuk menerapkan metode ini mungkin akan dijumpai kesulitan dalam penentuan tipe keputusan dan penentuan parameter secara tepat, karena untuk melakukan hal tersebut diperlukan pemahaman yang cukup baik dari metode PROMETHEE (Harsono et al., 2009).

Penelitian ini memiliki perbedaan dengan penelitian yang pernah dilakukan oleh Wang dan Yang. Perbedaannya yakni untuk pembobotan kriteria dalam penelitian ini akan dilakukan oleh 13 apoteker yang akan dihitung menggunakan metode AHP. Untuk perhitungan prioritas alternatif menggunakan preferensi linear dalam metode PROMETHEE, tipe preferensi linear dipilih dengan alasan tipe ini memiliki kelebihan dibandingkan dengan tipe preferensi lainnya karena tipe preferensi ini lebih bisa mengatasi permasalahan ketika perbandingan nilai antar kriteria sangat kecil, sehingga dari hasil perhitungannya terlihat perbedaannya. Mengenai keluaran yang akan ditampilkan pada penelitian ini sistem akan menampilkan prioritas alternatif dan grafik visualisasi prioritas alternatif.

Metode PROMETHEE dipilih dengan alasan metode ini menentukan prioritas yang lebih sederhana dalam analisa multikriteria, lebih jelas dalam perhitungan dan proses analisa data, sehingga diharapkan dapat menjadi solusi untuk menentukan pemasok yang terbaik secara objektif dan meminimalkan terjadinya penyalahgunaan wewenang pengambil keputusan.

\section{Kerangka Teori}

\subsection{Sistem Pendukung Keputusan}

Sistem Pendukung Keputusan (SPK) digunakan untuk membantu pengambil keputuasan dalam mengatasi permasalahan yang ada. SPK tidak dimaksudkan untuk mengotomatisasikan pengambilan keputusan. SPK mampu memberikan perangkat interaktif bagi pengambil keputusan untuk melakukan berbagai analisis data, menggunakan model yang tersedia (Kusrini, 2007).

\subsection{Metode AHP}

AHP dikembangkan Dr. Thomas L. Saaty dari Wharton School of Business pada tahun 1970-an untuk mengorganisasikan informasi dan judgement dalam memiliki alternatif yang paling disukai (Tominanto, 2012).

AHP adalah sebuah metode memecah permasalahan yang komplek/ rumit dalam situasi yang tidak terstruktur menjadi bagian-bagian komponen. Mengatur bagian atau variabel ini menjadi suatu bentuk susunan hierarki, kemudian memberikan nilai numerik untuk penilaian subjektif terhadap kepentingan relatif dari setiap variabel dan mensintesis penilaian untuk variabel mana yang memiliki prioritas tertinggi yang akan mempengaruhi penyelesaian dari situasi tersebut. AHP menggabungkan pertimbangan dan penilaian pribadi dengan cara yang logis dan dipengaruhi imajinasi, pengalaman, dan pengetahuan untuk menyusun hierarki dari suatu masalah yang berdasarkan logika, intuisi dan juga pengalaman untuk memberikan pertimbangan (Tominanto, 2012).

Prosedur dalam metode AHP terdiri dari beberapa tahap (Tominanto, 2012), yaitu:

1) Menyusun hirarki dari permasalahan yang dihadapi

Penyusunan hirarki yaitu dengan menentukan tujuan yang merupakan sasaran sistem secara keseluruhan pada level teratas. Level berikutnya terdiri dari kriteria-kriteria untuk menilai atau 
mempertimbangkan alternatif-alternatif yang ada dan menentukan alternatif-alternatif tersebut. Setiap kriteria dapat memiliki subkriteria di bawahnya dan setiap kriteria dapat memiliki nilai intensitas masingmasing.

2) Menentukan prioritas elemen

a. Langkah pertama dalam menentukan prioritas elemen adalah membuat perbandingan berpasangan, yaitu membandingkan elemen secara berpasangan sesuai kriteria yang di berikan dengan menggunakan bentuk matriks. Matriks bersifat sederhana, berkedudukan kuat yang menawarkan kerangka untuk memeriksa konsistensi, memperoleh informasi tambahan dengan membuat semua perbandingan yang mungkin dan menganalisis kepekaan prioritas secara keseluruhan untuk merubah pertimbangan. Proses perbandingan berpasangan dimulai dari level paling atas hirarki untuk memilih kriteria, misalnya $\mathrm{C}$, kemudian dari level dibawahnya diambil elemen-elemen yang akan dibandingkan, misal A1, A2, A3, A4, A5, maka susunan elemen-elemen pada sebuah matriks dapat dilihat pada Tabel 1.

Tabel 1. Matriks perbandingan berpasangan

\begin{tabular}{cccccc}
\hline $\mathrm{C}$ & $\mathrm{A} 1$ & $\mathrm{~A} 2$ & $\mathrm{~A} 3$ & $\mathrm{~A} 4$ & $\mathrm{~A} 5$ \\
\hline $\mathrm{A} 1$ & 1 & & & & \\
$\mathrm{~A} 2$ & & 1 & & & \\
$\mathrm{~A} 3$ & & & 1 & & \\
$\mathrm{~A} 4$ & & & & 1 & 1 \\
$\mathrm{~A} 5$ & & & & & 1 \\
\hline
\end{tabular}

b. Mengisi matriks perbandingan berpasangan yaitu dengan menggunakan bilangan untuk merepresentasikan kepentingan relatif dari satu elemen terhadap elemen lainnya yang dimaksud dalam bentuk skala dari 1 sampai dengan 9. Skala ini mendefinisikan dan menjelaskan nilai 1 sampai 9 untuk pertimbangan dalam perbandingan berpasangan elemen pada setiap level hirarki terhadap suatu kreteria di level yang lebih tinggi.

Apabila suatu elemen dalam matriks dan dibandingkan dengan dirinya sendiri, maka diberi nilai 1. Jika i dibanding j mendapatkan nilai tertentu, maka j dibanding i merupakan kebalikkannya. Berikut ini merupakan skala kuantitatif 1 sampai dengan 9 untuk menilai tingkat kepentingan suatu elemen dengan elemen lainnya seperti pada Tabel 2.

\section{c. Sintesis}

Pertimbangan-pertimbangan

terhadap perbandingan berpasangan di sintesis untuk memperoleh keseluruhan prioritas.

1) Menjumlahkan nilai-nilai dari setiap kolom pada matriks.
2) Membagi setiap nilai dari kolom dengan total kolom yang bersangkutan untuk memperoleh normalisasi matriks.

3) Menjumlahkan nilai dari setiap matriks dan membaginya dengan jumlah elemen untuk mendapatkan nilai rata-rata.

4) Mengukur konsistensi.

Tabel 2. Skala kuantitatif dalam metode AHP

\begin{tabular}{|c|c|c|}
\hline $\begin{array}{c}\text { Intensitas } \\
\text { Kepentingan }\end{array}$ & Arti/Makna & Penjelasan \\
\hline 1 & $\begin{array}{l}\text { Kedua elemen } \\
\text { sama } \\
\text { pentingnya }\end{array}$ & $\begin{array}{l}\text { Dua elemen mempunyai } \\
\text { pengaruh yang sama besar } \\
\text { terhadap tujuan }\end{array}$ \\
\hline 3 & $\begin{array}{l}\text { Elemen yang } \\
\text { satu sedikit } \\
\text { lebih penting } \\
\text { dari pada } \\
\text { elemen yang } \\
\text { lainnya }\end{array}$ & $\begin{array}{l}\text { Pengalaman dan penilaian } \\
\text { sedikit menyokong satu elemen } \\
\text { dibandingkan elemen yang } \\
\text { lainnya }\end{array}$ \\
\hline 5 & $\begin{array}{l}\text { Elemen yang } \\
\text { satu lebih } \\
\text { penting dari } \\
\text { pada elemen } \\
\text { lainnya }\end{array}$ & $\begin{array}{l}\text { Pengalaman dan penilaian } \\
\text { sangat kuat menyokong satu } \\
\text { elemen dibandingkan elemen } \\
\text { yang lainnya }\end{array}$ \\
\hline 7 & $\begin{array}{l}\text { Satu elemen } \\
\text { jelas lebih } \\
\text { mutlak penting } \\
\text { dari pada } \\
\text { elemen yang } \\
\text { lainnya }\end{array}$ & $\begin{array}{l}\text { Satu elemen yang kuat di } \\
\text { sokong dan dominan terlihat } \\
\text { dalam praktek }\end{array}$ \\
\hline 9 & $\begin{array}{l}\text { Satu elemen } \\
\text { mutlak penting } \\
\text { dari pada } \\
\text { elemen lainnya }\end{array}$ & $\begin{array}{l}\text { Bukti yang mendukung elemen } \\
\text { yang satu terhadap elemen lain } \\
\text { memiliki tingkat penegasan } \\
\text { tertinggi yang mungkin } \\
\text { menguatkan }\end{array}$ \\
\hline $2,4,6,8$ & $\begin{array}{l}\text { Nilai-nilai } \\
\text { antara } 2 \text { nilai } \\
\text { pertimbangan } \\
\text { yang berdekatan }\end{array}$ & $\begin{array}{l}\text { Nilai ini diberikan bila ada dua } \\
\text { kompromi diantara } 2 \text { pilihan }\end{array}$ \\
\hline Kebalikan & \multicolumn{2}{|c|}{$\begin{array}{l}\text { Jika aktifitas i mendapat satu angka dibanding } \\
\text { aktifitas j, maka j mempunyai nilai kebalikkannya } \\
\text { dibanding dengan i }\end{array}$} \\
\hline
\end{tabular}

Konsistensi penting untuk mendapatkan hasil yang valid dalam dunia nyata. AHP mengukur konsistensi pertimbangan dengan rasio konsistensi (consitency ratio). Nilai Konsistensi rasio harus kurang dari $5 \%$ untuk matriks $3 \times 3,9 \%$ untuk matriks $4 \times 4$ dan $10 \%$ untuk matriks yang lebih besar. Jika lebih dari rasio dari batas tersebut maka nilai perbandingan matriks di lakukan kembali. Langkahlangkah menghitung nilai rasio konsistensi yaitu:

a) Mengkalikan nilai pada kolom pertama dengan prioritas relatif elemen pertama, nilai pada kolom kedua dengan prioritas relatif elemen kedua, dan seterusnya.

b) Menjumlahkan setiap baris.

c) Hasil dari penjumlahan baris dibagikan dengan elemen prioritas relatif yang bersangkutan.

d) Membagi hasil diatas dengan banyak elemen yang ada, hasilnya disebut eigen value ( $\lambda \max )$, untuk matriks lihat Tabel 2.1.

e) Menghitung indeks konsistensi (consistency index) dengan rumus : 


$$
C I=(\lambda \max -n) / n
$$

dengan:

$C I=$ Consistency Index

$\lambda \max =$ Eigen Value

$n=$ Banyak elemen

f) Menghitung konsistensi ratio (CR) dengan rumus :

$$
C R=\frac{C I}{R C}
$$

dengan:

CR $=$ Consistency Ratio

$C I=$ Consistency Index

$R C=$ Random Consistency

Matriks random dengan skala penilaian 1 sampai 9 beserta kebalikkannya sebagai random consistency $(R C)$.

Berdasarkan perhitungan saaty menggunakan 500 sampel, jika pertimbangan memilih secara acak dari skala $1 / 9,1 / 8, \ldots, 1,2, \ldots, 9$ akan diperoleh rata-rata konsistensi untuk matriks yang berbeda seperti Tabel 3.

Tabel 3. Nilai rata-rata konsistensi

\begin{tabular}{cc}
\hline Ukuran Matriks & Konsistensi Acak \\
\hline 1 & 0,00 \\
2 & 0,00 \\
3 & 0,58 \\
4 & 0,90 \\
5 & 1,12 \\
6 & 1,24 \\
7 & 1,32 \\
8 & 1,41 \\
9 & 1,45 \\
10 & 1,49 \\
\hline
\end{tabular}

\subsection{Metode PROMETHEE}

PROMETHEE merupakan singkatan dari Preference Ranking Organization Methods for Enrichment Evaluations adalah metode outranking yang menawarkan cara yang fleksibel dan sederhana kepada user (pembuat keputusan) untuk menganalisis masalah-masalah multikriteria (Brans dan Vincke, 1985).

Dalam PROMETHEE terdapat enam bentuk fungsi preferensi kriteria. Meskipun tidak bersifat mutlak, namun bentuk-bentuk ini cukup baik untuk beberapa kasus (Novaliendry, 2009).

Tipe preferensi metode promethee yang digunakan dalam penelitian ini yakni preferensi liner. Tipe preferensi liner memiliki kelebihan dibandingkan dengan tipe preferensi lainnya karena tipe preferensi ini lebih bisa mengatasi permasalahan ketika perbandingan nilai antar kriteria sangat kecil, sehingga dari hasil perhitungannya terlihat perbedaannya. Berikut merupakan tipe preferensi linear (Brans dan Vincke, 1985):

$$
P(x)\left\{\begin{array}{c}
x / m, x \leq m \\
1, x>m
\end{array}\right.
$$

dengan:

$x=$ selisih nilai kriteria $\{x=f(a)-f(b)\}$

$m=$ nilai kecenderungan atas preferansi.

Kriteria preferensi linear menjelaskan bahwa selama nilai selisih memiliki nilai yang lebih rendah dari $\mathrm{m}$, maka preferensi dari pembuat keputusan akan meningkat secara linear dengan nilai x. Jika nilai $\mathrm{x}$ lebih besar daripada nilai $\mathrm{m}$, maka akan terjadi preferensi mutlak.

Pada saat pembuat keputusan mengidentifikasikan beberapa kriteria untuk tipe ini, ia harus menentukan nilai kecenderungan dari nilai $\mathrm{p}$. Dalam hal ini nilai $d$ di atas nilai $p$ telah dipertimbangkan akan memberikan preferensi mutlak dari suatu alternatif seperti Gambar 1 .

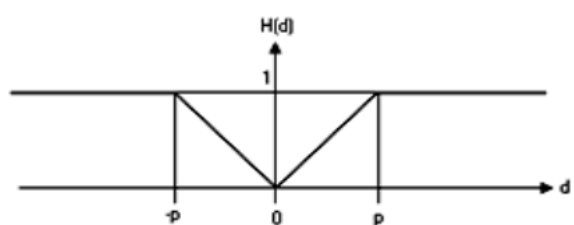

Gambar 1. Preferensi kriteria linear dengan parameter $p$.

\subsection{Penentuan Leaving Flow, Entering Flow dan Net} Flow.

Leaving flow $\left(\emptyset_{+}\right)$adalah jumlah nilai garis lengkung yang memiliki arah menjauh dari simpul a dan ini merupakan karakter pengukuran outranking. Selain itu juga merupakan suatu ukuran atau nilai yang menunjukkan kekuatan dari alternatif. Penentuan setiap simpul dalam grafik nilai outranking adalah berdasarkan leaving flow, dengan menggunakan persamaan:

$$
\emptyset^{+}(a)=\frac{1}{n-1} \sum_{x \in A} \rho(a, x)
$$

dengan:

$\rho(a, x)=$ menunjukkan preferensi alternatif $a$ lebih baik dari $x$.

$n=$ jumlah nilai.

Entering flow ( $\varnothing$-) merupakan suatu ukuran atau nilai yang menunjukkan kelemahan dari alternatif. Secara simetris dapat ditentukan entering flow dengan persamaan:

$$
\emptyset^{-}(a)=\frac{1}{n-1} \sum_{x \in A} \rho(x, a)
$$

Net flow $(\varnothing)$ menunjukkan suatu nilai total dari kekuatan dan kelemahan yang dimiliki oleh 
alternatif, dalam penentuannya menggunakan persamaan:

$$
\emptyset(a)=\emptyset^{+}(a)-\emptyset^{-}(a)
$$

\subsection{Pemasok}

Pemasok atau pemasok obat adalah pihak atau badan yang berurusan dalam penyediaan obat dan atau bahan obat. Para pemasok mungkin adalah agen, perantara, fasilitas distribusi, industri atau pedagang. Apabila memungkinkan, para pemasok harus mempunyai izin dari instansi yang berwenang (Peraturan Kepala BPOM Republik Indonesia Nomor HK.03.1.34.11.12.7542, 2012).

Semua sumber pasokan difokuskan pada kinerja mereka seperti sebagai pengiriman, kualitas, layanan dan harga sebagai faktor utama yang digunakan semua perusahaan untuk mengevaluasi sumber pasokan (Ha dan Krishnan, 2008).

\section{Metodologi}

\subsection{Bahan dan Alat Penelitian}

Bahan penelitian yang dibutuhkan dalam penelitian ini yakni kebutuhan informasi akan kriteria-kriteria yang diterapkan oleh perusahaan untuk memilih pemasok. Penelitian ini akan dilakukan di apotek untuk memilih pemasok obat, kriteria pemilihan pemasok yang akan digunakan diantaranya:

1. Kelengkapan obat

2. Harga

3. Waktu pengiriman

4. Pembayaran/jangka kredit

Selanjutnya untuk pembobotan setiap kriteria akan dilakukan dengan sistem pengisian kuesioner yang akan diisi oleh apoteker yang telah bekerja di apotek, kuesioner disebar ke beberapa apotek, meliputi: apotek sekitar Semarang, apotek sekitar Kudus, apotek sekitar Pati, apotek sekitar Rembang. Selain itu dalam penelitian ini dibutuhkan dokumentasi, buku-buku, serta literatur-literatur sebagai refrensi guna memperkuat penelitian ini.

Alat yang digunakan dalam penelitian ini yakni perangkat keras berupa laptop dengan spesifikasi:

1. Processor AMD-A6 2,10GHz.

2. RAM 4 GB.

3. Hard disk $500 \mathrm{~GB}$.

Selain itu juga menggunakan perangkat lunak berupa:

1. Microsoft Windows 8.1 sebagai sistem operasi untuk laptop.

2. Adobe dreamweaver CS6 digunakan untuk coding.

3. Microsoft Visio 2007 digunakan untuk desain perancangan sistem.

4. Rational Rose 2001 digunakan untuk perancangan $U M L$.

5. Database $M y S Q L$ digunakan sebagai database sistem.

\subsection{Prosedur Penelitian}

Beberapa tahapan yang dilakukan dalam penelitian ini yakni: identifikasi masalah, pengumpulan data, analisis dan perancangan sistem, dan pengujian sistem.

Tahapan-tahapan prosedur penelitian dapat dijelaskan sebagai berikut:

1) Identifikasi Masalah

Pada tahap ini akan dilakukan identifikasi masalah, menentukan masalah yang ada, dalam hal ini masalah yang dihadapi yakni memilih supplier yang terbaik.

2) Pengumpulan Data

Setelah masalah dapat diidentifikasi, tahap selanjutnya yakni mengumpulkan berbagai data untuk menyelesaikan masalah tersebut. Data-data yang dimaksud bisa berupa informasi yang didapat dari perusahaan, bisa berupa literatur seperti buku, jurnal, dan sumber ilmiah lainnya yang berhubungan dengan penelitian ini.

3) Analisis dan Perancangan Sistem

Selanjutnya pada tahap ini dilakukan proses analisis menggunakan metode AHP dan PROMETHEE. Arsitektur perancangan sistem dimulai dari:

a. Pemilihan supplier, supplier yang dimaksud yakni pemasok obat yang sudah mempunyai izin resmi/berbadan hukum yang melakukan pemasokan obat ke beberapa apotek.

b. Penilaian kriteria pemilihan supplier menggunakan metode AHP, kriteria pemilihan supplier yang digunakan: kelengkapan obat, harga/diskon, waktu pengiriman, pembayaran/jangka kredit. Penilaian kriteria dilakukan dengan menggunkan penyebaran kuesioner ke beberapa apoteker yang bekerja di apotek, meliputi: apotek sekitar Semarang, apotek sekitar Kudus, apotek sekitar Pati, apotek sekitar Rembang. Hasil data dari kuesioner akan di analisa menggunakan metode AHP.

c. Analisa data menggunakan metode PROMETHEE untuk pengambilan keputusan, hasil dari analisis metode AHP akan digunakan sebagai inputan untuk metode PROMETHEE. Metode PROMETHEE yang digunakan sebagai fungsi preferensi adalah tipe preferensi linear. Hasil analisa menggunakan metode PROMETHEE keluarannya berupa prioritas/rangking supplier obat.

d. Dashboard akan menampilkan rekomendasi berdasarkan prioritas pemasok obat yang layak untuk memasok obat ke apotek.Berikut merupakan kerangka sistem informasi pemilihan supplier seperti Gambar 2. 


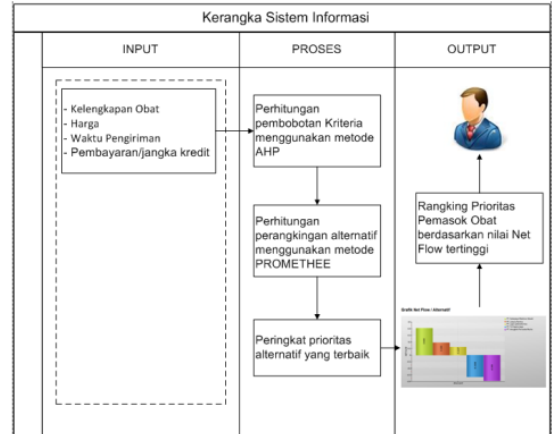

Gambar 2. Kerangka Sistem Informasi Pemilihan Supplier

\section{4) Pengujian Sistem}

Tahap selanjutnya yakni melakukan pengujian sistem. Untuk melakukan pengujian sistem yang diuji mengenai analisis data yang telah diproses oleh sistem dibandingkan dengan perhitungan di file exel dan pengujian mengenai performa dari sistem ini.

\section{Hasil dan Pembahasan}

\subsection{Hasil Penelitian}

Hasil yang didapat dari penelitian ini yang pertama berupa pembobotan kriteria pemilihan supplier obat, pembobotan kriteria menggunakan data kuesioner, yang bertindak sebagai responden yakni para apoteker, penyebaran kuesioner untuk para apoteker meliputi Kabupaten Rembang, Kabupaten Pati, Kabupaten Kudus, Kabupaten Demak, Kota Semarang, dari 13 kuesioner yang telah terisi terdapat 1 penilaian yang tidak konsisten berdasarkan perhitungan konsistensi rasio menggunakan metode AHP. Data kuesioner yang telah diisi oleh para apoteker terdapat dalam lampiran.

Berikut merupakan perhitungan pembobotan kriteria menggunakan metode AHP berdasarkan penilaian yang telah diisi oleh para apoteker:

Nama Apoteker : Puji Sri Harningsih, S.Farm, Apt

Nama Apotek : Ramayana

Alamat Apotek : Jl. P. Diponegoro 49 Rembang
Caranya adalah dengan mengalikan tiap cell pada baris yang sama. Dipangkatkan dengan jumlah kriteria.

$\begin{array}{lll}\text { Kelengkapan Obat } & =(1 * 1 / 5 * 1 * 1)^{\wedge}(1 / 4) & =0,669 \\ \text { Harga } & =(5 * 1 * 5 * 3)^{\wedge}(1 / 4) & =2,943 \\ \text { Waktu Pengiriman } & =(1 * 1 / 5 * 1 * 5)^{\wedge}(1 / 4) & =1 \\ \text { Pembayaran/ } & & \\ \text { Jangka Kredit } & =(1 * 1 / 3 * 1 / 5 * 1)^{\wedge}(1 / 4) & =\frac{0,508}{5,120} \\ \pm & & \end{array}$

2) Menghitung bobot prioritas tiap kriteria

Untuk menghitung bobot prioritas caranya adalah nilai eigen value untuk tiap kriteria dibagi dengan total eigen value.

$\begin{array}{lll}\text { Kelengkapan Obat } & =0,669 / 5,120 & =0,131 \\ \text { Harga } & =2,943 / 5,120 & =0,575 \\ \text { Waktu Pengiriman } & =1 / 5,120 & =0,195 \\ \text { Pembayaran/ } & & \\ \text { Jangka Kredit } & =0,508 / 5,120 & =0,099\end{array}$

Menentukan validitas bobot sebagai berikut:

1) Menjumlahkan tiap kolom

\begin{tabular}{|c|c|c|}
\hline Kelengkapan Obat & $=1+5+1+1$ & $=8$ \\
\hline Harga & $=1 / 5+1+1 / 5+1 / 3$ & $=1,73$ \\
\hline $\begin{array}{l}\text { Waktu Pengiriman } \\
\text { Pembayaran/ }\end{array}$ & $=1+5+1+1 / 5$ & $=7,2$ \\
\hline Jangka Kredit & $=1+3+5+1$ & $=10$ \\
\hline
\end{tabular}

2) Membagi tiap sel dari kolom berdasarkan hasil penjumlahan langkah 1 .

Tabel 5. Perhitungan Konsistensi Penilaian Apotek Ramayana Rembang

\begin{tabular}{|c|c|c|c|c|}
\hline Kriteria & $\begin{array}{l}\text { Kelengkapan } \\
\text { Obat }\end{array}$ & Harga & $\begin{array}{l}\text { Waktu } \\
\text { Pengiriman }\end{array}$ & $\begin{array}{l}\text { Pembaya } \\
\text { ran/ } \\
\text { Jangka } \\
\text { kredit }\end{array}$ \\
\hline $\begin{array}{l}\text { Kelengkapa } \\
\text { n Obat }\end{array}$ & $1 / 8=0,125$ & $\begin{array}{c}0,2 / 1,73= \\
0,115\end{array}$ & $1 / 7,2=0,139$ & $1 / 10=0,1$ \\
\hline Harga & $5 / 8=0,625$ & $\begin{array}{c}1 / 1,73= \\
0,577\end{array}$ & $5 / 7,2=0,694$ & $3 / 10=0,3$ \\
\hline $\begin{array}{l}\text { Waktu } \\
\text { Pengiriman }\end{array}$ & $1 / 8=0,125$ & $\begin{array}{c}0,2 / 1,73= \\
0,115\end{array}$ & $1 / 7,2=0,139$ & $5 / 10=0,5$ \\
\hline $\begin{array}{l}\text { Pembayara } \\
\text { n/ Jangka } \\
\text { Kredit }\end{array}$ & $1 / 8=0,125$ & $\begin{array}{c}0,3 / 1,73= \\
0,192\end{array}$ & $\begin{array}{c}0,2 / 7,2= \\
0,028\end{array}$ & $1 / 10=0,1$ \\
\hline
\end{tabular}

Tabel 4. Hasil Penilaian Apotek Ramayana Rembang

\begin{tabular}{lcccc}
\multicolumn{1}{c}{ Kriteria } & $\begin{array}{l}\text { Kelengkapan } \\
\text { Obat }\end{array}$ & Harga & $\begin{array}{l}\text { Waktu } \\
\text { Pengirim } \\
\text { an }\end{array}$ & $\begin{array}{l}\text { Pembaya } \\
\text { ran/ } \\
\text { Jangka } \\
\text { kredit }\end{array}$ \\
\hline $\begin{array}{l}\text { Kelengkapan } \\
\text { Obat }\end{array}$ & 1 & $1 / 5$ & 1 & 1 \\
$\begin{array}{l}\text { Harga } \\
\text { Waktu }\end{array}$ & 5 & 1 & 5 & 3 \\
$\begin{array}{l}\text { Pengiriman } \\
\begin{array}{l}\text { Pembayaran/ } \\
\text { Jangka Kredit }\end{array}\end{array}$ & 1 & $1 / 5$ & 1 & 5 \\
\hline
\end{tabular}

Langkah-langkah dalam menentukan bobot kriteria adalah sebagai berikut:

1) Menghitung Eigen Value
3) Menghitung bobot sintesa

Cara menghitung bobot sintesa yakni menjumlahkan per baris hasil dari langkah 2 .

Kelengkapan Obat $\quad=0,125+0,115+0,139+0,1=0,479$

Harga $\quad=0,625+0,577+0,694+0,3=2,196$

Waktu Pengiriman $\quad=0,125+0,115+0,139+0,5=0,879$

Pembayaran/

Jangka Kredit $\quad=0,125+0,192+0,028+0,1=0,445$

4) Menghitung Eigen Maksimum

Untuk menghitung eigen maksimum dilakukan dengan cara membagi bobot sintesa dengan bobot prioritas. Hal ini dilakukan untuk tiap kriteria
Kelengkapan Obat $=0,479 / 0,131=3,67$
Harga $=2,196 / 0,575=3,82$
Waktu Pengiriman $=0,879 / 0,195=4,50$ 
Pembayaran/ Jangka Kredit $=0,445 / 0,099=\frac{4,48+}{16,48}$ $\lambda \max =(x) /$ jumlah kriteria $=16,48 / 4=4,12$

\section{5) Menguji konsistensi}

$\mathrm{CI}=(\lambda \max -$ jumlah kriteria $) /$ jumlah kriteria-1)

$\begin{aligned} & =(4,12-4) /(4-1)=0,04 \\ \mathrm{CR} & =\mathrm{CI} / \mathrm{IR}=0,04 / 0,9=0,04\end{aligned}$

Nilai konsistensi $0,04 \leq 0,1$ maka dikatakan KONSISTEN

Berdasarkan hasil perhitungan metode AHP dari 13 penilai terdapat 1 penilai yang tidak konsisten, maka akan diambil 12 penilaian yang konsisten selanjutnya dihitung rata-rata pembobotan masingmasing kriteria. Berikut merupakan rata-rata pembobotan masing-masing kriteria seperti Tabel 6 .

Tabel 6. Perhitungan Rata-rata Bobot Kriteria

\begin{tabular}{ccccc}
\hline Apoteker & $\begin{array}{l}\text { Kelengkapa } \\
\text { n Obat }\end{array}$ & $\begin{array}{l}\text { Harga/ } \\
\text { Diskon }\end{array}$ & $\begin{array}{l}\text { Waktu } \\
\text { Pengiriman }\end{array}$ & $\begin{array}{l}\text { Pembaya } \\
\text { ran/ } \\
\text { Jangka } \\
\text { Kredit }\end{array}$ \\
\hline Puji Sri & 0,1306 & 0,5748 & 0,1953 & 0,0993
\end{tabular}

\begin{tabular}{|c|c|c|c|c|}
\hline Puji Sri & 0,1306 & 0,5748 & 0,1953 & 0,0993 \\
\hline $\begin{array}{l}\text { Harningsih, } \\
\text { S.Farm, Apt }\end{array}$ & & & & \\
\hline $\begin{array}{l}\text { Ispriyati, } \\
\text { S.Farm, Apt }\end{array}$ & 0,1988 & 0,4445 & 0,2973 & 0,0595 \\
\hline $\begin{array}{l}\text { Nurida, } \\
\text { S.Farm, Apt }\end{array}$ & 0,4946 & 0,2360 & 0,2170 & 0,0525 \\
\hline $\begin{array}{l}\text { Esti } \\
\text { Kurniawati, } \\
\text { S.Farm, Apt }\end{array}$ & 0,6275 & 0,0666 & 0,1998 & 0,1061 \\
\hline $\begin{array}{l}\text { Emmy } \\
\text { Sulistyowati, } \\
\text { S.Farm, Apt }\end{array}$ & 0,3692 & 0,1396 & 0,3394 & 0,1518 \\
\hline $\begin{array}{l}\text { Moh. } \\
\text { Syaifudin, } \\
\text { S.Si, Apt }\end{array}$ & 0,2303 & 0,0907 & 0,5250 & 0,1540 \\
\hline $\begin{array}{l}\text { Nurjanah, } \\
\text { S.Farm, Apt }\end{array}$ & 0,1646 & 0,1251 & 0,2166 & 0,4938 \\
\hline $\begin{array}{l}\text { Asteria Danik } \\
\text { W., S.Farm, } \\
\text { Apt }\end{array}$ & 0,3001 & 0,3950 & 0,1317 & 0,1733 \\
\hline $\begin{array}{l}\text { Niken } \\
\text { Puspitasari, } \\
\text { S.Farm, Apt }\end{array}$ & 0,0993 & 0,1306 & 0,5748 & 0,1953 \\
\hline $\begin{array}{l}\text { Tan Aviana } \\
\text { Sanwijaya, } \\
\text { S.Farm, Apt }\end{array}$ & 0,1340 & 0,4019 & 0,2321 & 0,2321 \\
\hline $\begin{array}{l}\text { Tri Istiyani, } \\
\text { S.Farm, Apt }\end{array}$ & 0,2401 & 0,1606 & 0,3591 & 0,2401 \\
\hline $\begin{array}{l}\text { Sholihul } \\
\text { Umam, } \\
\text { S.Farm, Apt }\end{array}$ & 0,1462 & 0,1462 & 0,2186 & 0,4889 \\
\hline Rata-rata & 0,2613 & 0,2426 & 0,2922 & 0,2039 \\
\hline
\end{tabular}

Berikut merupakan data nilai alternatif pemasok yang akan digunakan dalam perhitungan:
Tabel 7. Nilai Alternatif Supplier

\begin{tabular}{ccccc}
\hline Tipe & III & III & III & III \\
\hline Kaidah & Max & Max & Min & Max \\
Parameter & 3 & 3 & 1 & 10 \\
Bobot & 0,2613 & 0,2426 & 0,2922 & 0,2039 \\
Kriteria & C1 & C2 & C3 & C4 \\
A1 & 3 & 4 & 2 & 30 \\
A2 & 2 & 3 & 1 & 32 \\
A3 & 2 & 3 & 1 & 30 \\
A4 & 3 & 3 & 1 & 35 \\
A5 & 4 & 4 & 1 & 30 \\
\hline
\end{tabular}

Berdasarkan data yang ada pada Tabel 7 akan diperoleh nilai leavingflow, enteringflow. Nilai tersebut dapat dilihat pada Tabel 8. Dari Tabel 8 akan didapatkan nilai net flow yang digunakan untuk memilih pemasok obat. Nilai tersebut dapat dilihat pada Tabel 9.

Proses penentuan prioritas diurutkan berdasarkan nilai netflow terbesar sampai terkecil. Nilai A5 menjadi prioritas utama kemudian setelah itu A4, A1, A2, dan yang terakhir A3.

Aplikasi sistem dapat dijalankan oleh user melalui browser. Tampilan sitem dapat dilihat pada Gambar 3.

Tabel 8. Matriks Perhitungan Preferensi

\begin{tabular}{ccccccc} 
Alternatif & A1 & A2 & A3 & A4 & A5 & leaving \\
\hline A1 & & 0,4194 & 0,4602 & 0,2711 & 0,2051 & 0,3389 \\
A2 & 0,1650 & & 0,3330 & 0,1439 & 0,0779 & 0,1800 \\
A3 & 0,1242 & 0,2514 & & 0,1032 & 0,0371 & 0,1290 \\
A4 & 0,3133 & 0,4405 & 0,4813 & & 0,2262 & 0,3653 \\
A5 & 0,3793 & 0,5065 & 0,5473 & 0,3582 & & 0,4478 \\
entering & 0,2455 & 0,4044 & 0,4554 & 0,2191 & 0,1366 & \\
\hline
\end{tabular}

Tabel 9. Nilai Net Flow

\begin{tabular}{cccc}
\hline Alternatif & Leaving & Entering & Net Flow \\
\hline A1 & 0,3389 & 0,2455 & 0,0935 \\
A2 & 0,1800 & 0,4044 & $-0,2245$ \\
A3 & 0,1290 & 0,4554 & $-0,3264$ \\
A4 & 0,3653 & 0,2191 & 0,1462 \\
A5 & 0,4478 & 0,1366 & 0,3112 \\
\hline
\end{tabular}

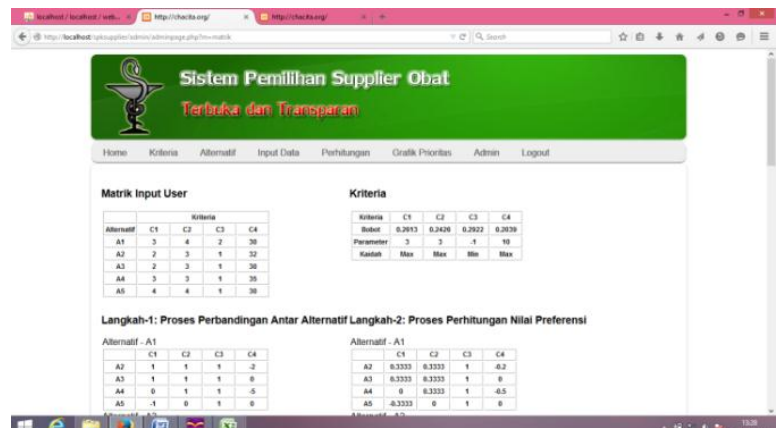

Gambar 3. Halaman Perhitungan Prioritas Alternatif 


\subsection{Pembahasan}

Berdasarkan hasil penelitian di atas dapat diketahui prioritas alternatif, selanjutnya dibandingkan dengan hasil implementasi sistem yang ada di atas, dari pembobotan untuk masing-masing kriteria oleh setiap penilai dihitung menggunakan metode AHP, sampai dengan perhitungan prioritas alternatif dihitung menggunakan metode PROMETHEE. Dengan menggunakan masukan yang sama, dari hasil perhitungan manual dan perhitungan sistem mengeluarkan keluaran yang sama, sehingga dapat diketahui bahwa sistem pemilihan pemasok menggunakan metode AHP dan PROMETHEE dapat digunakan dengan baik, cepat dan mudah.

Secara nyata proses memilih pemasok obat yang terjadi di lapangan, apoteker memilih pemasok obat dengan cara membaca daftar harga obat yang dibawa oleh pemasok obat, para apoteker dalam memilih pemasok obat menggunakan 4 kriteria yakni kelengkapan obat, harga, waktu pengiriman, serta pembayaran atau jangka kredit. Masing-masing apoteker bisa cenderung mementingkan salah satu dari 4 kriteria tersebut, oleh karena itu peneliti melakukan penelitian ini untuk menyatukan penilaian atau kecenderungan yang dilakukan oleh para apoteker terhadap 4 kriteria tersebut yang dihitung menggunakan metode AHP.

Khusus untuk kriteria kelengkapan obat, pemasok obat dikatakan memiliki kelengkapan obat sangat lengkap yang menentukan adalah apoteker dengan cara melihat daftar harga yang telah dibawa oleh pemasok obat, berdasarkan hasil wawancara peneliti dengan para apoteker serta wawancara dengan dosen farmasi, mereka menyatakan bahwa apoteker mempertimbangkan kebutuhan obat untuk apotek berdasarkan pola penyakit. Dari hasil wawancara tersebut peneliti menyimpulkan bahwa untuk kriteria kelengkapan obat sifatnya masih sedikit subjektif, karena untuk mengisi kriteria tersebut perlu didasari pemikiran apoteker dengan membaca daftar obat. Saran untuk peneliti selanjutnya lebih mengembangkan kriteria-kriteria pemilihan pemasok obat, khususnya pada apotek yang hanya menjual obat-obat penyakit khusus.

Berdasarkan hasil penelitian di atas dapat diketahui bahwa penilaian matriks perbandingan yang dilakukan oleh 13 apoteker dan telah dihitung menggunakan metode AHP terdapat 1 penilaian yang tidak konsisten, selanjutnya diambil 12 penilaian yang konsisten dan dirata-rata untuk menghasilkan pembobotan kriteria. Berdasarkan uraian tersebut dapat diketahui bahwa penilai satu dengan penilai lainnya saling berkaitan dan saling mempengaruhi dalam melakukan penilaian matriks perbandingan antar kriteria untuk mendapatkan bobot kriteria.

Hasil penilaian matriks perbandingan antar kriteria yang dilakukan oleh para apoteker menghasilkan bobot kriteria, sehingga semakin banyak penilai matriks perbandingan antar kriteria akan didapatkan bobot kriteria yang lebih akurat untuk proses perhitungan prioritas alternatif.

Berdasarkan perhitungan prioritas alternatif menggunakan metode PROMETHEE telah diketahui alternatif (A5) dengan nilai net flow 0,3112 merupakan prioritas utama. Dalam perhitungan prioritas alternatif menggunakan metode PROMETHEE digunakan preferensi linear atau preferensi tipe III, mengapa dalam perhitungan prioritas alternatif dipilih preferensi linear, dari hasil penelitian dapat menjawab bahwa preferensi linear bisa mengatasi permasalahan ketika perbandingan nilai antar kriteria sangat kecil, sehingga dari hasil perhitungannya terlihat perbedaannya (bisa dilihat tabel 4.10), dari tabel 4.10 diketahui alternatif (A2) dan alternatif (A3) mempunyai nilai yang hampir mirip yang membedakan hanya nilai pada kriteria pembayaran atau jangka kredit dimana (A2) memiliki nilai 32 dan (A3) memiliki nilai 30 ada selisih 2 angka, selisih 2 angka dihitung dengan preferensi linear dapat menghasilkan keluaran berbeda, peneliti telah mencoba dengan selisih nilai 0,1 antar alternatif perhitungan preferensi linear juga dapat menghasilkan keluaran yang berbeda.

Perhitungan prioritas alternatif menggunakan metode PROMETHEE dengan preferensi linear terdapat parameter dan kaidah, untuk mendapatkan nilai parameter didapatkan dari pengambil keputusan atau yang menentukan adalah pengambil keputusan, nilai parameter setiap kriteria bisa berbeda tergantung standart nilai yang telah ditentukan oleh pengambil keputusan untuk masing-masing kriteria. Mengenai kaidah dalam metode PROMETHEE dengan preferensi linear terdapat kaidah maksimasi dan minimasi, setiap kriteria dapat memiliki kaidah maksimasi atau minimasi, kriteria dapat diberi kaidah maksimasi apabila pengambil keputusan menginginkan nilai alternatif yang akan dimasukankan semakin besar memungkinkan alternatif tersebut prioritasnya semakin baik, sebaliknya apabila kriteria ingin diberi kaidah minimasi maka pengambil keputusan mengmasukankan nilai alternatif semakin kecil memungkinkan alternatif tersebut prioritasnya semakin baik.

Penelitian ini memiliki perbedaan dengan penelitian yang pernah dilakukan oleh Wang dan Yang. Perbedaannya yakni untuk pembobotan kriteria dalam penelitian ini akan dilakukan oleh 13 apoteker yang akan dihitung menggunakan metode AHP. Untuk perhitungan prioritas alternatif menggunakan preferensi linear dalam metode PROMETHEE. Sedangkan penelitian yang dilakukan oleh Wang dan Yang menggunakan 1 penilai untuk melakukan pembobotan kriteria menggunakan metode AHP.

Hasil uraian pembahasan diatas dibandingkan dengan penelitian sebelumnya yang telah dilakukan oleh Harsono et al. didapatkan perbedaan yang 
terdapat dalam pembobotan kriteria yang dilakukan oleh para penilai menggunkaan metode AHP, dimana dalam penelitian sebelumnya menggunakan 5 penilai untuk melakukan penilaian matriks perbandingan kriteria, untuk masing-masing kriteria menggunakan preferensi yang berbeda. Sedangkan dalam penelitian ini untuk mendapatkan pembobotan kriteria dilakukan penilaian matriks perbandingan kriteria yang telah dinilai oleh 13 penilai, telah dijelaskan perhitungan pembobotan kriteria sampai dengan perhitungan konsistensi rasio menggunakan metode AHP sehingga diketahui dari 13 penilai terdapat 1 penilaian yang tidak konsisten, diambil 12 penilaian yang konsisten dan hasilnya dirata-rata sehingga didapatkan pembobotan untuk masing-masing kriteria, dari hasil tersebut dapat diketahui bahwa semakin banyak penilai yang penilaiannya konsisten akan menghasilkan bobot kriteria yang lebih akurat, bobot kriteria ini yang nantinya akan mempengaruhi hasil keluaran prioritas alternatif, karena apabila bobot kriteria berubah maka keluaran prioritas alternatif akan ikut berubah.

\section{Kesimpulan}

Berdasarkan hasil penelitian, pembahasan serta implementasi sistem terhadap implementasi metode AHP dan PROMETHEE untuk pemilihan pemasok obat dapat disimpulkan sebagai berikut:

1. Sistem ini dapat menghasilkan prioritas alternatif pemasok obat dari nilai Net Flow tertinggi.

2. Semakin banyak penilai yang melakukan pembobotan kriteria akan menghasilkan bobot kriteria yang objektif.

3. Sistem ini bekerja secara dinamis, pengguna dapat menambah kriteria yang diinginkan berapapun jumlahnya, serta dapat menambah alternatif berapapun jumlahnya. Pengguna dapat mengatur indikator setiap kriteria.

4. Sistem ini menyediakan fasilitas pembobotan kriteria secara manual, serta menyediakan pembobotan kriteria berdasarkan penilaian dari penilai yang profesional.

\section{Daftar Pustaka}

Akincilar A., and Dagdeviren M., 2014. A hybrid multi-criteria decision making model to evaluate hotel websites. International Journal of Hospitality Management, 36, 263- 271.

Albadvi, A., Chaharsooghi S.K., dan Esfahanipour A., 2007. Decision making in stock trad-ing: an application of PROMETHEE. European Journal of Operational Research, 177, 673-683.
Brans, J.P., Vincke, PH. and Mareschal, B., 1986. How to select and how to rank projects: The PROMETHEE method. European Journal of Operational Research, 24, 228-238.

Brans, J.P., Vincke PH., 1985. A Preference Ranking Organisation Method (The PROMETHEE Method for Multiple Criteria Decision-Making). Management Science Vol. 31, No. 6.

Ha, Ho S., and Krishnan, R., 2008. A hybrid approach to supplier selection for the maintenance of a competitive supply chain. Expert Systems with Applications, 34, 13031311.

Harsono, A., Prassetyo H., Arqom N., 2009. Metode Pemilihan Pemasok Sayuran di Supermarket dengan Metode AHP dan PROMETHEE (Studi kasus di PT. Hero Supermarket Cabang Suci Bandung). Jurnal Itenas Rekayasa, Vol. XIII, No. 4.

Kusrini, 2007. Konsep dan Aplikasi Sistem Pendukung Keputusan, Edisi Pertama, Andi, Yogyakarta.

Novaliendry, D., 2009. Aplikasi Penggunaan Metode Promethee dalam Sistem Pendukung Keputusan untuk Penentuan Media Promosi Studi Kasus: STMIK Indonesia. Jurnal Ilmiah Kursor, Vol. 5, No. 2.

Peraturan Kepala BPOM Republik Indonesia Nomor HK.03.1.34.11.12.7542, 2012.

Safari, H., Fagheyi, M.S., Ahangari, S.S., and Fathi, M.R., 2012. Applying PROMETHEE Method based on Entropy Weight for Supplier Selection. Business management and strategy, Vol. 3, No. 1.

Tominanto, 2012. Sistem Pendukung Keputusan dengan Metode Analytical Hierarchy Process (AHP) untuk Penentuan Prestasi Kinerja Dokter pada RSUD. Sukoharjo. INFOKES, VOL. 2 NO. 1 .

Vinodh S., dan Girubha R.J., 2012. PROMETHEE based sustainable concept selection. International Journal Applied Mathematical Modelling, 36, 5301-5308.

Wang Jian-Jun, dan Yang De-Li, 2006. Using a hybrid multi-criteria decision aid method for information systems outsourcing. Computers \& Operations Research, 34, 3691 - 3700.

Yu X., Xu Z., dan Ma Y., 2013. Prioritized MultiCriteria Decision Making Based on the Idea of PROMETHEE. Procedia Computer Science, 17, 449-456. 